\title{
The ordered disintegration of nuclear DNA as a specific genome reaction accompanying apoptosis, stress response and differentiation
}

\author{
V. T. Solovyan*, I. O. Andreev, T. Yu. Kolotova', \\ P. V. Pogrebnoy ${ }^{2}$, D. V. Tamavsky \\ Instinte of Molecular Biology and Genetics of the National Academy of Sciences of Ukraine \\ 150 Zabolotnogo str., Kyiv 252143, Ukraine \\ '1. I. Mechnikov Institute of Microbiology and Immunology \\ Kharkiv 131057, Ukraine \\ ${ }^{2}$ R. E. Kavetsky Institute of Experimental Pathology, Oncology and Radiobiology of the National \\ Academy of Sciences of Ukraine \\ 45 Vasylkivska str., Kyiv 252022, Ukraine
}

\begin{abstract}
The treatment of agarose embedded nuclear or cellular preparations with protein denaturing agents resulted in ordered cleavage of intact nuclear DNA into high molecular weight fragments with the pattern of fragmentation being unityped for various eukaryotic representatives. We showed that the set of DNA fragments represents the pre-existing DNA structural domains attributed to the higher levels of chromatin folding, and presented evidence allowing to interpret the nuclear DNA domain organization as a constituent component of topoisomerase II/DNA complex with its ability to mediate the cleavage/religation reactions. We demonstrated that changes in the integrity of nuclear DNA, recognizable as an altered pattern of SDS-dependent cleavage of nuclear DNA into high molecular weight DNA fragments, took place at the early stage of apoptosis, upon number of stress challenges and in cells showing vorious proliferative status. The changes in the integrity of nuclear DNA affected by various influences were shown to be prompt and seem to be of transient nature. The results obtained allow to conclude that changes in the integrity of nuclear DNA revealed as an altered pattern of SDS-dependent high molecular weight DNA cleavage may present the specific genome reaction accompanying the physiological changes in the cells during apoptosis, stress response and differentiation.
\end{abstract}

Introduction. Genomic DNA within eukaryotic cell nucleus appears to be organized into loop domains sized about $40-100 \mathrm{~kb}$, which are fixed on the protein backbone structure referred to as nuclear matrix or chromosome scaffold [1-11]. Topoisomerase II have been shown to be a major component of the nuclear matrix and chromosome scaffold fraction and play important role in chromosome structure and condensation and in genome expression [12-14]. Several lines of evidence suggest that type II enzyme appears to be concentrated in a number of discrete anchoring complexes, which probably form the basis of the chromatin loop domains $[15,16]$. The organization of nuclear DNA into loop domains provides reasons to believe that each structural domain may correspond to individual functional genome unit, which is compartmentalized

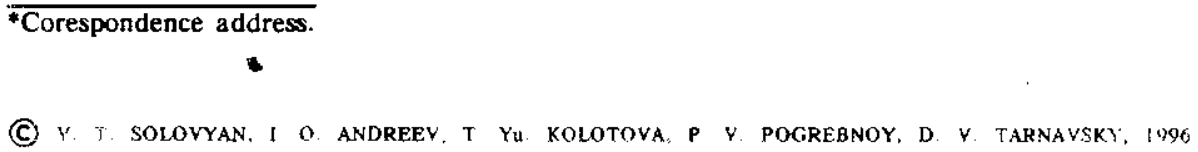


relative to regulatory elements by DNA sequences that are bound to the nuclear matrix [17-22] (for review see [19]). Several investigators reported that changes in DNAse I sensitivity that can extend over several cozens of kilobases accompany changes in expression of specific genes [23, 24] (for review see [3]), with the boundaries of transcriptionally active nuclease-sensitive domains being commonly coincided with matrix attachment regions [25-28]. In a number of studies using a variety of fractionation techniques both replicating DNA and transcriptionally active sequences were shown to exhibit an altered interaction with nuclear matrix $[11,29-35]$ (for review see $[19,33-35]$ ). These data indicate that some functionally significant structural rearrangements of chromatin may occur during DNA replication and transcription.

Recently it was shown that the formation of discrete set of high molecular weight (HMW) DNA fragments proceeds at the early stages of apoptosis [36, 37 ], which may be interpreted as a key event involved in the programmed cell death $[38,39]$. This finding suggests that the ordered disintegration of nuclear DNA into HMW-DNA fragments may represent an early event in specific cell programme resulting in cell self-demise.

In the present investigation we report data to show that the changes in the integrity of nuclear DNA accompany various cell programmes including apoptosis, stress response, proliferation and may be interpreted as a specific genome reaction being of physiological value.

Material and Methods. Cell lines and culture conditions. The human lymphoblastoma cultured cells (line CEM) and primary cell culture of murine thymocytes obtained from the thymus of $4-5$ week old mouse (line BALB/c) were used for investigation of apoptosis and stress response. Human cultured cells were routinely incubated in RPMI 1640 medium supplemented with $10 \%$ fetal calf serum (FCS) in atmosphere of $95 \%$ air, $5 \% \mathrm{CO}_{2}$ to give a final suspension of $5 \cdot 10^{6}$ cells $/ \mathrm{ml}$. Thymocyte primary culture was prepared from intact thymocytes to final suspension of $2 \cdot 10^{7}$ cells in RPMI $1640 / 10 \%$ FCS and incubated under conditions indicated above for at least $6 \mathrm{~h}$ either with or without apoptotic inducers. Apoptosis was induced by incubation of cells either with $1 \mu \mathrm{M}$ dexamethasone or $7.5 \mu \mathrm{M}$ teniposide (VM-26). The cell survival fraction was estimated by Trypan blue exclusion.

Preparation of cellular samples to FIGE fractionation. $200 \mu \mathrm{l}$ of cell suspension were placed into the well of cell culture plate followed by addition of equal volume of $1 \%$ low-melting point agarose prepared on TEN-buffer (10 $\mathrm{mM}$ Tris- $\mathrm{HCl}, \mathrm{pH} 7.5,1 \mathrm{mM}$ EDTA, $150 \mathrm{mM} \mathrm{NaCl}$ ). After gelation the equal volume of lysing buffer (TEN $+1 \%$ SDS) was layered followed by incubation for $1 \mathrm{~h}$ at $37^{\circ} \mathrm{C}$. Agarose plugs containing the lysed cells were used for analysis by agarose gel electrophoresis.

Gel electrophoresis. Lysed cell preparations were fractionated either by conventional or field inversion gel electrophoresis (FIGE) to detect the pattern of nuclear DNA cleavage. Conventional gel electrophoresis was carried out in $1.4 \%$ agarose at $50 \mathrm{~V}$ for $4-5 \mathrm{~h}$ using $0,5 \times \mathrm{TBE}$ buffer $(0.089 \mathrm{M}$ Tris, $0.089 \mathrm{M}$ boric acid, $0.002 \mathrm{M}$ EDTA, $\mathrm{pH} 8.5$ ). FIGE was performed in $1 \%$ agarose at $85 \mathrm{~V}$ for $18 \mathrm{~h}$ in $0,5 \times \mathrm{TBE}$ buffer under constant pulses of electric field ( $24 \mathrm{~s}$ «forward» and $8 \mathrm{~s}$ «backward») allowing to monotonous resolution of DNA molecules sized up to $500 \mathrm{~kb}$ [50]. In some cases FIGE was carried out for 5-6 h allowing to resolve both low- and high molecular weight DNA. After electrophoresis the gel was stained with $1 \mu \mathrm{g} / \mathrm{ml}$ ethidium bromide for $10 \mathrm{~min}$, viewed using UV transilluminator and photographed using Mikrat 300 film.

Results and Discussion. We showed in our previous works that the fractionation of agarose embedded nuclei samples, treated with SDS, by field inversion gel electrophoresis (FIGE) results in appearence of two main types of discrete DNA fragments sized about $50-100 \mathrm{~kb}$ and $250-300 \mathrm{~kb}$, with the 
pattern being comparable for various eukaryotic representatives [40]. The treatment of nuclei preparations with protein denaturing agents represents the decisive prerequisite for ordered HMW-DNA cleavage. No DNA fragment is released into gel provided these agents lacking even if nuclei were destroyed with high concentration of EDTA [40].

$\mathrm{Re}$-fractionation of nuclear preparations by FIGE with various pulsed field switching intervals or by orthogonal field alteration gel electrophoresis (OFAGE) showed that the group of DNA fragments of about 250-300 kb contributes to the limited mobility zone under FIGE employed while the another group of DNA represents the set of DNA fragments with the real size of about $50-100 \mathrm{~kb}$ (results not shown).

As evidenced from the data presented in Fig. 1, the pattern of SDS-depen-

Fig. 1. The pattern of lymphocytes nuclear DNA fragmentation in cells $(I)$, nuclei (2) and nucleoids (3) preparations. Human lymphocytes were collected

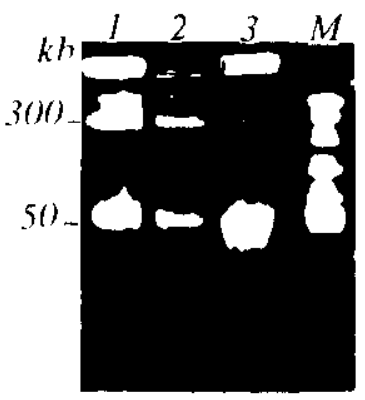
by centrifugation, resuspended in $T E$-buffer containing $0.15 \mathrm{M} \mathrm{NaCl}$ and embedded into lowmelting agarose. After gelation samples were treated with $1 \%$ SDS followed by FIGE fractionation. For preparation of nuclei, cells were resuspended in buffer containing $10 \mathrm{mM}$ Tris $-\mathrm{HCl}(\mathrm{pH} 8.0), 5 \mathrm{mM}$ $\mathrm{MgCl}_{2}, 1 \%$ triton $\mathrm{X}-100,0.32 \mathrm{M}$ sucrose. After centrifugation nuclear peilet was resuspended in the same buffer without triton followed by addition of equal volume of $1 \%$ agarose. Nucleoids (histonedepleted nuclei) were prepared by extensive nuclei treatment with $2 \mathrm{M} \mathrm{NaCl}$ followed by embedding into agarose. After gelation nuclei and nucleoid preparations were treated with $1 \%$ SDS and fractionated by FIGE. $M-$ molecular weight standards, lambda DNA oligomers

dent HMW-DNA cleavage is similar to that found in fractionated cell-, nucleiand «nucleoid» preparations. The only difference is that in the nucleoids DNA fragments of about $50-100 \mathrm{~kb}$ represent the major DNA cleaved product. The maintaining of an ordered nuclear DNA fragmentation in nucleoids (histonedepleted nuclei) suggests that the HMW-DNA fragments revealed by FIGE may be relevant to the higher-level DNA structural organization. Based on the data of structural organization of histone-depleted nuclei, it is conceivable to ascribe the observed 50-100 kb DNA fragments to DNA loop domains the average length of which varies between $40-100 \mathrm{~kb}[10,41]$.

Data presented in Fig. 2 show that nuclear DNA structural domains seem to be involved in functioning topoisomerase II/DNA complex with the main ability to carry out cleavage/rejoining reactions. Thus, the specific modulator of topoisomerase II activity, teniposide (VM-26), enhances the ordered HMWDNA cleavage which results in the increased amount of DNA released into gel and in breaking down of the large DNA fragments into $50-100 \mathrm{~kb}$ ones. (Fig. $2, B$, line 1,2$)$. On the other hand, the conditions provoked by the Fig. 2. Modulation of topoisomerase $\mathbf{I}$-mediated cleavage/religation reactions in cultured human cells: $A$-cultured lymphoblastoma cells (line CEM) were incubated at $37{ }^{\circ} \mathrm{C}(l)$, subjected at $4{ }^{\circ} \mathrm{C}$ for $30 \mathrm{~min}(2)$ followed by incubation at 37 ${ }^{\circ} \mathrm{C}$ for $30 \mathrm{~min}(3) ; B$ - the same cells were incubated at $37^{\circ} \mathrm{C}$ without $(I)$ or with $7.5 \mu \mathrm{M}$ teniposide (2) for 20 min followed teniposide treatment the cells were incubated at $55^{\circ} \mathrm{C}$ for 10 min (3) $(A, B$ - after incubation cells were embedded into agarose, treated with SDS and fractionated by FIGE)
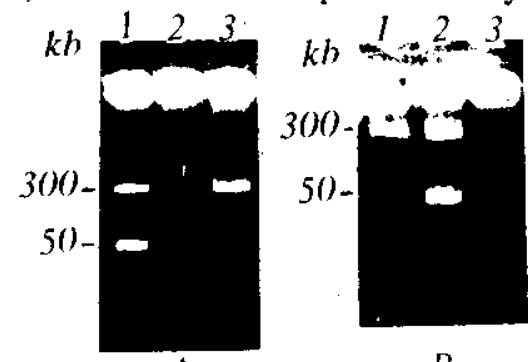

A
$B$ 
topoisomerase II-mediated reverse reaction lead to the rejoining of cleaved DNA domains (Fig. 2).

The ordered disintegration of nuclear DNA into HMW-DNA domains seems to be of physiological value since the formation of HMW DNA fragments may be involved in the early events accompanying programmed cell death. This is evidenced from the data presented in Fig. 3, which show that the

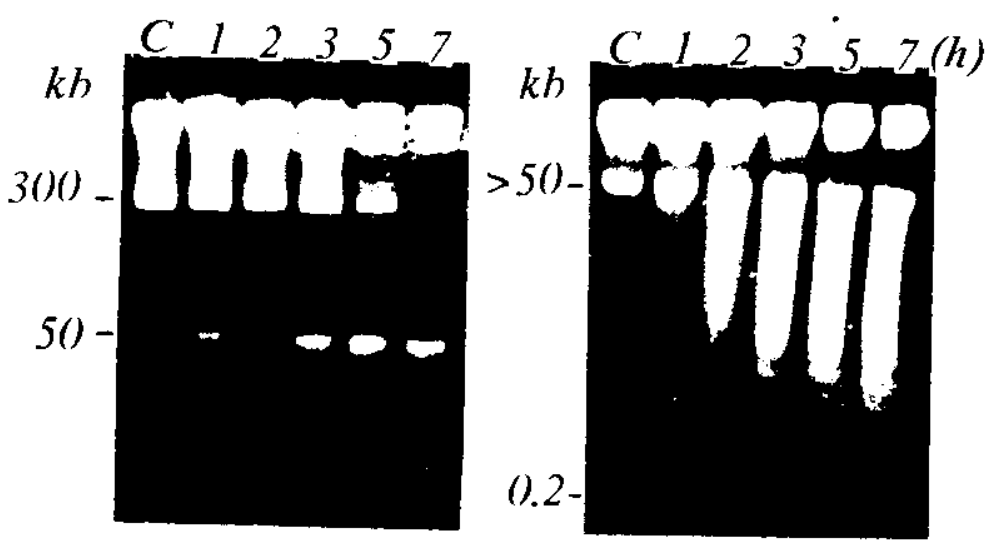

Fig. 3. Gel electrophoretic analysis of nuclear DNA cleavage during dexamethasone induced apoptosis in murine thymocytes. Cells were treated with $1 \mu \mathrm{M}$ dexamethasone and allowed to incubate for the time indicated at the top of the Figure. After incubation cells were embedded into low-melting point agarose, treated with SDS and fractionated either by FIGE (top panels) or conventional gel electrophoresis (bottom panels). $C$ - control celis (not treated with dexamethasone)

dexamethasone induced apoptosis in primary culture of thymocytes is associated with enhanced nuclear DNA cleavage into fragments of about $50-100 \mathrm{~kb}$, which is detectable at the early stage of apoptosis and precedes typical for apoptosis internucleosomal DNA fragmentation. It seems likely, however, that the ordered HMW-DNA cleavage is not restricted to apoptotic cell death. The data presented in Fig. 4 show that in vitro incubation of primary culture of thymocytes without apoptotic inducers is accompanied with the rapid increase of nuclear HMW-DNA cleavage to be kept «frozen» without typical for apoptosis oligonucleosomal «ladden development. These data suggest that ordered

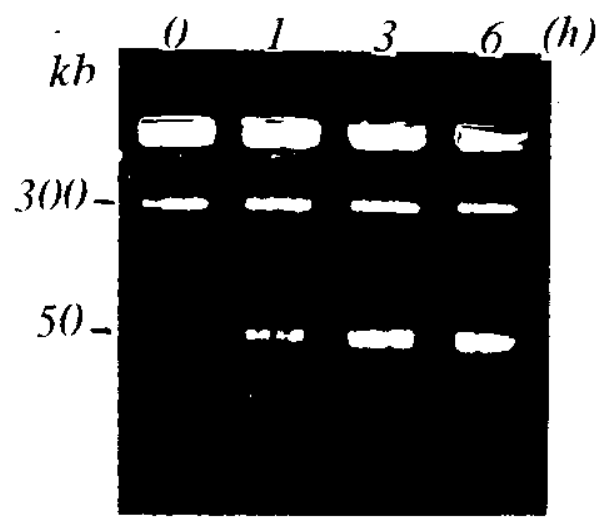

Fig. 4. Gel electrophoretic analysis of nuclear DNA cleavage in primary culture of thymocytes nonstimulated to apoptosis. Intact murine thymocytes were resuspended in RPMI medium supplemented with $10 \%$ FCS and allowed to incubate for the time indicated at the top of the Figure (h). After incubation cells were embedded into low-melting point agarose, treated with SDS and fractionated by FIGE 
disintegration of nuclear DNA revealed as an enhanced HMW-DNA cleavage contribute not only to the apoptosis but may be implicated in cell response to stress challenges induced by thymocyte introduction in to in vitro culture. As a confirmation to this may be data presented in Fig. 5, indicating that both
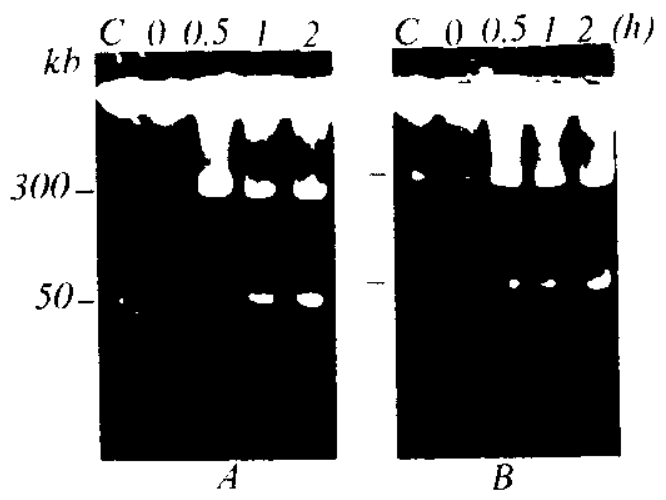

Fig. 5. The pattem of ordered DNA cleavage in cultured CEM cells in response to cold shock. Cells were incubated for $10 \mathrm{~min}$ at $4{ }^{\circ} \mathrm{C}(A)$ or $1 \mathrm{~h}$ at $15^{\circ} \mathrm{C}(B)$ followed by incubation at $37^{\circ} \mathrm{C}$ for the time indicated at the top of figure $(h)$. After incubation cells were embedded into low-melting point agarose, treated with SDS and fractionated by FIGE. $C \rightarrow$ control cells not subjected to shock

short-time acute and prolong gentle cold shock appear to induce in cultured human lymphoblastoma cells (line CEM) rapid changes in the pattern of HMW-DNA cleavage which is invariably persistent for at least $2 \mathrm{~h}$ recovering after cold shock.

As evidenced from the data presented in Fig. 6 the ordered disintegration of nuclear DNA into HMW-DNA fragments may be of transient nature. Thus, cultured CEM cell incubation in serum-free medium is accompanied by the increased formation of HMW-DNA fragments to be rapidly declined following serum addition and practically disappeared after $24 \mathrm{~h}$ incubation with fresh medium with serum (Fig. 6). Similarly, the dilution of monolayer HeLa cells with fresh medium is also associated with rapid changes in the pattern of SDS-dependent HMW-DNA cleavage (Fig. 7). The generation of HM W-DNA fragments is progressively decreased during cell incubation in fresh medium and completely disappeared after $24 \mathrm{~h}$ of incubation. However, after $2 / 3$ of new monolayer has been established, the formation of HMW-DNA is resumed (Fig. 7).

These data indicate that changes in the pattern of SDS-dependent HMW-DNA cleavage, seem to be of transient nature, and may be implicated not only in cell response to stress challenges but also to accompany the changes in the proliferation status of the cell. It allows to interpret the changes in the integrity of nuclear DNA structural domains as a specific genome reaction being of physiological value.

Our data show that the treatment of agarose-embedded nuclear or cellular preparations with SDS results in ordered fragmentation of nuclear DNA into HMW-DNA fragments with the pattern of fragmentation being comparable for various eukaryotic representatives. The maintaining of an ordered nuclear DNA fragmentation in histone-depleted nuclei (Fig. 1) suggests that the formation of HMW-DNA fragments appears to be independent on the presence of histones and may be due to the periodicity of DNA folding in the cell nucleus. This provides reasons to believe that HMW-DNA fragments revealed by FIGE fractionation of SDS treated nuclear preparations represent pre-existing structural domains to reflect the higher levels of chromatin organization.

Based on the data of structural organization of histone-depleted nuclei, it 


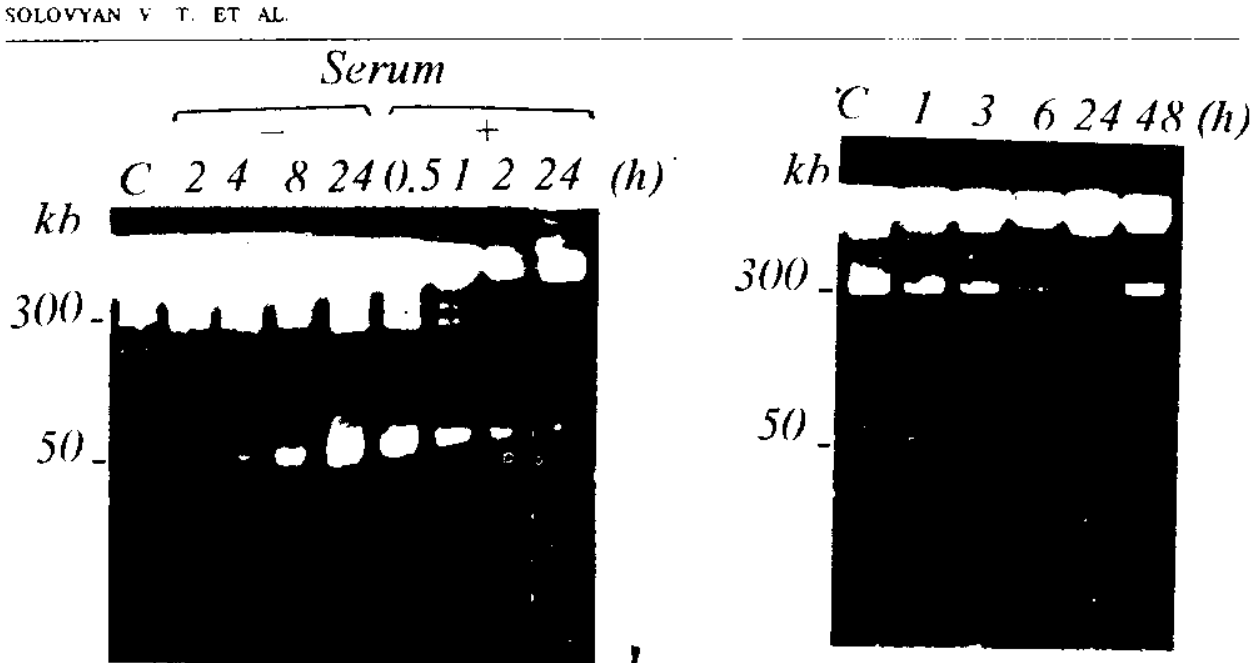

Fig. 6. The transient nature of ordered DNA cleavage in cultured CEM cells during serum starvation. Cells were incubated in serum-free medium (-) for the time indicated at the top of figure (h). Following starvation serum was added and cells were incubated in serum-containing medium $(+)$ for the time indicated at the top of figure $(h)$. After incubation cells were embedded into agarose, treated with SDS and fractionated by FIGE. $C$ - control cells before serum starvation

Fig. 7. The transient nature of ordered DNA cleavage in cultured HeLa cells. Monolayer cells were washed with cultural medium to remove dead cells and treated with tripsine to obtain cellular suspension. Portion of cellular suspension was embedded into agarose to analyse nuclear DNA cleavage (control cells $-C$ ), while the equal another portions were supplemented with fresh medium and allowed to incubate for the time indicated at the top of figure $(\mathrm{h})$. After incubation cells were washed with cultural medium to remove dead cells, tripsinized, collected by centrifugation and embedded into agarose followed by SDS treatment and FIGE fractionation

is conceivable to ascribe the $50-100 \mathrm{~kb}$ DNA fragments to DNA loop domains the average length of which varies between $40-100 \mathrm{~kb}[10,41]$. Similar results were obtained by other authors as well [42-44]. As far as $250-300 \mathrm{~kb}$ DNA fragments are concerned these contribute to the limited mobility zone under FIGE employed and may be interpreted as a heterogeneous population of DNA fragments consisting of noncleaved loop domains. This is supported by the fact that these fragments may be converted into $50-100 \mathrm{~kb}$ ones by a number of influences including topoisomerase II specific poisons [40]. The sensitiveness of SDS-dependent HMW-DNA cleavage to topoisomerase II-specific poison teniposide and rejoining of cleaved HMW-DNA domain under conditions specifically stimulating the topoisomerase II-mediated religation reaction (Fig. 2) add credence to the idea that the nuclear DNA structural domains are involved in functioning topoisomerase II/DNA complex the main property of which is its ability to mediate the cleavage/rejoining reactions.

Our data evidence that the pattern of SDS-dependent HMW-DNA cleavage may follow the physiological changes in the cells thus suggesting that changes in the integrity of nuclear DNA may be of physiological value. Thus, the enhanced HMW-DNA cleavage was shown to be the early event involved in programmed cell death. Comparable data were obtained recently by other investigators [36-39] to demonstrate that the formation of HMW-DNA fragments may be considered as a biochemical hallmark of apoptosis.

Our results indicate that changes in the integrity of nuclear DNA revealed as an altered pattern of SDS-dependent HMW-DNA cleavage occur not only during apoptosis but upon cell challenging with stress stimuli (Fig. 3-6). Since any stress influence may interfere with cellular viability one should believe that the increased HMW-DNA fragmentation may reflect the fact that cells become predisposed to apoptosis. The same reason may be for the monolayer HeLa cells, which show the increased formation of HMW-DNA fragments (Fig. 7). 
However, our data show that the ordered disintegration of nuclear DNA in apoptotic thymocytes seems to be uncoupled with apoptosis-specific internucleosomal DNA cleavage and takes place in those thymocytes not stimulated to apoptosis (Fig. 4). In addition, the quite different pattern of HMW-DNA cleavage may be observed even in the same plant tissues showing various differentiation level (like shoots and roots of pea seedlings). As evidenced from the results in all cases under study there is a tendency to enhanced HMW-DNA fragmentation in quiescent or terminally differentiated tissues, which is revealed as a changed proportion between the two types of DNA fragments towards $50-100 \mathrm{~kb}$ fragments increase [51].

These results suggest that HMW-DNA cleavage seems to be unrelated with apoptosis-specific nuclear DNA degradation, but more likely represent the cellular response being of physiological value. This is further supported by the observation that formation of HMW-DNA fragments seems may be of transient nature (Fig. 6, 7). Taken together our results suggest that there may be a specific cellular response resulting in structural rearrangements of nuclear DNA domains, which accompany the physiological changes in the cells during various cellular programmes including apoptosis, stress response and differentiation. Our interpretation of ordered HMW-DNA cleavage is based on previously obtained data showing that nuclear DNA structural domains are involved in functioning topoisomerase II/DNA complex [45]. We demonstrated that the properties of this complex are comparable with those described for in vitro established complex purified enzyme/plasmide DNA [46, 47]. The main property of this complex was shown to be its ability to mediate the cleavage/rejoining reactions of DNA structural domains ([45]; Fig. 2, present communication). Based on the studies with purified topo II enzymes and DNA the two-stage model for topoisomerase II-mediated cleavage/religation reactions has been proposed [46, 47]. According to this model an enzyme/DNA cleavable complex is the key covalent in: rmediate in the topoisomerase II mediated DNA turnover, being in rapid equiıirium with noncleavable complex [46-48]. The exposure of the cleavable complex but not noncleavable one to protein denaturants (such as SDS or alkali) results in cleaved DNA product involving the covalent linking of topoisomerase II subanits to the $5^{\prime}$-ends of broken DNA $[46,47]$. Proceeding from the results that structural domains of nuclear DNA contribute to the functioning topoisomerase II/DNA complex [45] it seems appropriate to interpret the ordered disintegration of nuclear DNA into HMW-DNA fragments as DNA structural domain turnover from «noncleavable» to «cleavable state, mediated by topo II enzymes. Thus, our results allow to conclude that changes in the integrity of nuclear DNA revealed as an altered pattern of SDS-dependent HMW DNA-cleavage may present the specific genome reaction accompanying the physiological changes in the cells. This reaction may be interpreted as the turnover of structural domains between «cleavable» and «noncleavable» state whose physiological value remains to be elucidated.

This study was supported in part by Grant of Fund «Fundamental Research» of State Committee of Science and Technology, project 5.3/140.

В. Т. Солов'ян, І. О. Андреєв, Т. Ю. Колотова, П. В. Погребной, Д. В. Тарнавський

Упорядкована дезинтеграція ядерної ДНК Фк специфічна геномна реакція, що супроводжує anorro3, відповідь на стрес і диференціювання

Резгоме

У дакій роботі показано, цю при діт на «запrаялені ө асарозу препарати клітин та ядер білкових денатурантіо өіјбуєасться упорядковане крупноблочне розиеплення інтактної ядерної ДНК. Фрагменти, чр утворюються при цьому, являють собою передіскуючі структурні домени 
SOLOVYAN $\vee$ T. ET AL.

ядерної ДНК, які відповіданть вищим рівням упакування хроматину. ПХ ножна розслядати як конститутивний компонеят ядерного комплексу ДНК/ топоізомераза $/$, сиромохносо зійснювати реакцію розщепұення - воз'єднання дНК Встановлено, що зміна нативності, ао̆о цілісності. ядерної дНК, яка виявляється у зміні характеру DS-Na-захежного крупноб̆лочного розицелтення ядерної ДНК. відбувається на ранніх етапах апоптозу під дією різноманітних стресових факторів, и також у клітинах з різним рівнем проліферативиоі актияності. Отримані результати дозволяють припустити, ию спостережені зміни натияності ядерноі ¿НК можуть бути слецифічною геномною реакцією, яка супроводжує фізіолосічні прочеси е ктітині при апоптозі, відповіді на стрес ао̆о діференціювання

\section{В. э. Соговєян, Н. О. Андреев, Т. Ю. Колотова, П. В. Погреб̆ной, Д. В. Тарнавский}

у порядоченная лезинтеграция ядерной ДНК как специфическая геномная реакция сопровождающая апоптоз, ответ на стресс и дифференцировку

Резюме

В банной работе показано, что воздействие на препараты "заплавзенных" в ацарозу кұтокити ядер белковых денатурантов приводит к упорядоченному крупноблочному расщептению интактной ядерной ДНК. Фрасменты. образующиеся при этом, являют собой предсуцествующие структурные домены ядерной ДНК, соответствующие высщим уровня.к упаковки хроматина. Их можно рассматривать как конститутивный компонент ядерного комплекса ДНК/топоизомераза II. способ̆ного осуществлять реакцию расиепления / воссоединения дНК. Устанювлено, что изненение нативности, или челостности. ядерной ДНК, проявляющееся в изменении характера DS-Na-зависи.мосо крупноблочного расиепления ядерной ДНК, происходит на ранних этапах апоптоза под влиянием всевозможных стрессовьх факторов, а также в клетках с разинным уровнем пролиферативной активности. Эти изменения происходят быстро и мосут иметь обратимый характер. Полученнье результаты позволяют предполохить, что наблюдаемые шзменения нативности ядерной ДНК могут представ.дть собой специфическую геномную реакцию. сопровождающую физиологические процессы в клетке при апоптозе, ответе на стресс ити дифференцировке.

\section{REFERENCES}

1. Mirkovitch J., Mirault M.-E., Laemmli $U . K$ Organization of the higher order chromatin loop: specific DNA attachment sites on nuclear scaffold // Cell $-1984-39-\mathrm{P} .223-232$.

2. Pardoll D. M., Vogelstein B., Coffey D. S. A fixed site of DNA replication in eukaryotic cells // Ibid.-1980.-19.-P. 527-537.

3. Gasser S. M., Laemmli $U . K$ A glimpse at chromosomal order // Trends Genet. - 1987.--3.P. $16-22$.

4. Paulson J. R., Laemmli U. K. The structure of histone-depleted metaphase chromosomes // Cell. $-1977 .-12$-P. $817-828$.

5. Adolph $K, W$. Cheng $S . M$., Laemmli $U . K$. Role of non-histon proteins in metaphase chromosome structure // Ibid. -P. 805-816.

6. Benyajati C., Worcel A. Isolation, characterization, and structure of the folded interphase genome of Drosophila melanogaster // Ibid.-1976.-9.-P. 393-407.

7. Cook P. R., Brazell I. A. Conformational constraints in nuclear DNA // J. Cell. Sci.-1976.22.-P. 287-302.

8. Adolph $K W$. Isolation and structural organization of human mitotic chromosomes // Chromosoma. - 1980.-76.-P. 23-33.

9. Lebkowski J. S., Laemmli $U . K$ Non-histone proteins and long-range organizations of HeLa interphase DNA // J. Mol. Biol. $-1982 .-156 .-P$. 325-344.

10. Ward W. S., Partin A. W., Coffey D. S. DNA loop domains in mammalian spermatozoa $/ /$ Chromosoma. $-1989 .-98 .-$ P. $153-159$.

11. Vogelstein B., Pardoll D. M., Coffey D. S. Supercoiled loops and eukaryotic DNA replication // Cell. $-1980 .-22 .-P .79-85$.

12. Earnshaw W. C. Heck M. M. S. Localization of topoisomerase II in mitotic chromosomes // J Cell. Biol. $-1985 .-100 .-P .1716-1725$.

13. Berrios $M$., Osheroff $N$., Fisher $P$. A. In situ localization of DNA topoisomerase II, a major polypeptide component of Drosophila nuclear. matrix fraction // Proc. Nat. Acad. Sci. USA.-1985.-82.-P. $4142-4146$.

14. Cockerill $P . N$, Garrard $W . T$. Chromosomal loop anchorage of the kappa immunoglobulin gene occurs next to the enhancer in a region containing topoisomerase II sites $/ /$ Cell. $-1986 .-44$. P. $273-283$.

15. Sperry A. O., Blasquez V. C., Garrard W. T. Dysfunction of chromosomal loop attachment sites Illegitimate recombination linked to matrix association region and topoisomerase II // Proc. Nat. 
Acad. Sci. LSA. - 1989.-86.-P. 5497-5501

16. Idachi Y., Kas E., Luemmli U.K. Preferential, ccoperative binding of DNA topoisomerase II to scaffold-associate regions // EMBO J.-1989.-8.-P. 3997-4006.

17 Sippel A. E., Stief A., Hecht A. et al. The structural and functional domain organization of the chicken lysozyme gene locus // Nucl. acids and mol. biol. / Eds F Eckstein, D. M. I. Lilley. - Berlin: Heidelberg: Springer, 1989. - Vol. 3.-P. 133-147.

18. Murilley M., Gassend-Bonnet $G$. Supercoiled loop domains, expression units, and replicon organization in rDNA from Xenopus laevis // Exp. Cell. Res.-1989.-180.-P. 475-389.

19 Cook $P$. R. The nucleosketeton and the topology of transcription // Eur. J. Biochem. -1989. 185.-P. 487-501.

20 Gurrard W. T. Chromosomal loop organization in eukaryotic genomes // Vucl. acids and mol biol. / Eds F. Eckstein, D. M. I. Litley,-- Berlin; Heidetberg: Springer, 1989.-Vol 4.-P. $163-175$.

21. Georgiev G. P., Vassetsky Y. S., Luchnik A. N. et al. Nuclear Sceleton, DNA domains and control of replication and transcription // Eur. J. Biochem.-1991.-200.-P. 613-624.

22. Roberge M., Gasser S. M. DNA loops: stuctural and functional properties of scaffold-attached regions // Mol. Microbiol.-1992.-6.-P. 419-423.

2.3 Weintraub H., Groudine $M$. Chromosomal subunits in active genes have an altered conformation // Science. $-1976 .-193 .-$ P. $848-856$

24. Weisbrod $S$ Active chromatin // Nature--1982.-297.-P. 289-295

25. Phi-Van L. Stratling $W$. H. The matrix attachment regions of the chicken lysozyme gene co-map with the boundaries of the chromatin domain // EMBO J.-1988.-7.-P. 655-664.

2.6 Bode J., Maass $K$. Chromatin domain surrounding the human interferon-b gene as defined by scaffold-attached regions // Biochemistry. - 1989.-27.-P. 4706-4711.

27. Jarman A. P., Higgs $D$. R. Vuclear scaffold attachment sites in human globin gene complexes // EMBO J.-1988.-7.-P. 3337-3344.

28. Levy-Wilson B., Fortier C. The limits of the DNAse I-sensitive domain of the human apolipoprotein $B$ gene coincide with the locations of the chromosomal anchorage loops and define the $5^{\prime}$ and $3^{\prime}$ boundaries of the gene // J. Biol. Chem. - 1990.-264-P. 2119621204.

$\therefore$ berezney R., Cofjey D. S. Nuclear protein matrix: association with newly synthesized DNA // Sitence.-1975.-189.-P. $291-293$.

30. McCready S. J., Godwin J., Mason D. W. et al. DNA is replicated at the nuclear cage // J Cell. Sci. - 1980.-46.-P. 365-386.

31 Robinson S. I., Small D., Idzerda $R$. et al. The association of transcriptionally active genes with the nuclear matrix of the chicken oviduct // Nucl Acids Res.-1983.-11 -P. 51135130 .

32. Gerdes M. G., Canter K.C., Moen P. T., Lawrence J. B. Dynamic thanges in the higher-order chromatin organization of specific sequences revealed by in situ hybridization to nuclear hato // J. Cell. Biol.-1994.-126, N 2.-P. 289-304.

33. Berezney $R$. The nuclear matrix: a heuristic model for investigating genomic organization and function in the cell nucleus $/ / \mathrm{J}$. Cell. Biochem. -1991.-47.-P. 109-123.

34 Zlatunova J. S., van Holde $K$. E. Chromatin loops and transcriptional regulation // Crit. Revs Euk. Gene Expr.-1992.-2.-P. $211-224$

35. Bodnar J. W. A domain model for eukaryotic DNA organization: a molecular basis for cell differentiation and chromosome evolution // J. Theor. Biol. - 1998. - 132.-P. 479-507.

36. Walker P. R., Kokileva L. LeBlanc J., Sikorske M. Detection of the initial stages of DNA fragmentation in apoptosis // BioTechniques. $-1993 .-15$, N 6.-P. 1032-1040.

37. Brown $D$. G., Sun $X$. M., Cohen $G$. M. Dexamethasone-induced apoptosis involves cleavage of DNA to iarge fragments prior to internucleosomal fragmentation // J. Biol. Chem.-1993. 268. -P. 3037-3039

38. Obeshammer F. Wilson J.W., Dive C. et al. Apoptotic death in epithelial cells: cleavage of DNA to 300 and/or $50 \mathrm{~kb}$ fragments prior to or in the absence of internucleosomal Iragmentation // EMBO J - 1993-12 - P 3679-3684

39. Cohen G. M. Sun X.-M. Fearnhead H. et al. Formation of large molecular weight fragments of DNA is a key commitment step of apoptosis in thymocytes // I. Immunol.-1994.-153.P. $507-516$.

40. Solovyan V. T., Andreyev 1. O., Kunakh V. A. The tractionation of eukaryotic DNA by puised field gel electrophoresis. II. The discrete DNA fragments and the levels of chromatin structural organization // Mol. Biol. (Russia).-1991,-25. N 6.-P. 1483-1491

$\$ 1$ luemmli U. K. Cheng S. M. Adolph $K W$. et al Metaphase chromosome strucrure: The role of nonhistone proteins // Cold Spring Harbor Svmp. Quant. Biol. - 1978.-42.-P. $351-360$.

42. Filipski J.. LeBlanc J., Youdale $I$. et al. Periodicity of DNA iolding in higher order chromatin structure // EMBO J.- $1990-9 .-P^{2}, 1314 \ldots-\ldots 327$.

aj Razin S. V., Petrov P., Hancock R. Precise localization of the a-globin gene cluster within one of the 20- to 300-kilobase DNA fragments released by cleavage of chicken chromosomal DNA 
SOLOVYAN V. T. ET AL.

at topoisomerase II sites in vivo: Evidence that the fragments are DNA loops or domains $/ /$ Proc. Nat. Acad. Sci. USA. - 1991.-88.-P. 8515-8519.

44. Targa $F . R$., Razin S. V., Gallo $C . V . D$., Scherer $K$. Excision close to matrix attachment regions of the enttre chicken $\alpha$-globin gene domain by nuclease $S 1$ and characterization of framing structures // Ibid. - 1994.-91, N 10.-P. 4422-4426.

45. Solovyan V. T., Andreyev 1 . O., Kunakh V. A. The functional organization of plant nuclear DNA. I. Evidence for nuclear topoisomerase Il/DNA complex // Mol. Biol. (Russia). - 1993.27. N 6.-P. $770-774$.

46. Osheroff $N$. Biochemical basis for the interaction of type I and II topoisomerases with DNA // Pharmacol. Ther.-1989.-41.-P. 223-241.

47. Liu $L F$. DNA topoisomerase poisons as antitumor drugs // Annu. Rev. Biochem. - 1989.58. -P. $351-375$.

48. Nelson $E$. $M$. Tewey $K$. M. Liu $L F$. Mechanism of antitumor drug action: Poisoning of mammalian DNA topoisomerase II on DNA by 4 -(9-acridinylamino)-methanesulfon- $m$ anisidide // Proc. Nat. Acad. Sci. USA. -1984. -81.-P. 1361-1365.

49. Smith $H$. S., Berezney $R$. Nuclear matrix-bound deoxyribonucleic acid synthesis: An in vitro system // Biochemistry. -1982.-21.-P. 6752-6761.

50. Hellet C., Pohl F. M. A systematic study of field inversion gel electrophoresis // Nucl. Acids Res. $-1989 .-17 .-$ P. 5989-6003.

51. Solov'yan $V . T$., Andreev $1 . O$. The physiological significance of nuclear DNA structural domain disintegration: evidence for non-random DNA domain cleavage // Biopolymers and Cell. 1995.-11, N 5.-P. 51-55. 